\title{
Gott und Wissenschaft
}

\author{
Erster Band
}




\section{E. von Cyon \\ Gott und Wissenschaft}

Erster Band

Psychologie der großen Naturforscher

Autorisierte deutsche Ausgabe

Mit dem Bildnis des Verfassers von J. C. Chaplain

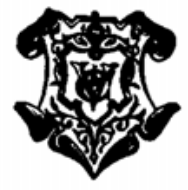

Leipzig

Verlag von Veit \& Comp.

1912 
Druck von Metzger \& Wittig in Leipzig. 
